\title{
Soil erosion in the south bank of the Brahmaputtra River in and around Hatishal, Jorhat District, Assam, India
}

\author{
Ajit Borkotoky ${ }^{1}$ and *B.P. Duarah ${ }^{2}$ \\ ${ }^{1}$ Department of Geology, Dimoria College, Khetri-782 403, Assam, India \\ ${ }^{2}$ Department of Geological Sciences, Gauhati University, Guwahati-781 014, India \\ (*Email: bpduarah@yahoo.com)
}

\begin{abstract}
The Brahamaputra River is a major river in Indian subcontinent. Flood and bank erosion in the Brahmaputra River is a serious problem all along its course. This paper is an attempt to understand the nature of sub-soil and causes of bank erosion in and around Hatishal area in Jorhat District of Assam, India. The study shows that the large scale erosion took place in the area between the years 1915 and 1967 and the likely effect was due to 1950 Assam earthquake of magnitude 8.5 M. The bank line migration is due to change in thalwegs position in the Brahmaputra. The bank materials dominated by poorly graded soil (SP) with little clay signify poor binding force for the materials and are the causes of bank erosion. The erosion related land and property losses are mainly due to active flood plain occupation by the people where the Brahmaputra River erodes and builds the bank periodically, the period may give time range in decades.
\end{abstract}

Keywords: Soil erosion, sub-soil, bank line migration, Brahmaputra river, Hatishal, Assam

Received: 14 November 2010

\section{INTRODUCTION}

Bank erosion, inundation of human habitation and agricultural land are the acute problems facing by Hatishal area (Duarah et al. 2008). Occurrence of bills and huge marshy tract are common in the valley. The erosion has become more acute since the great earthquake in 1950 when the river bed heaved upwards enormously causing heavy bank erosion.

The Brahamaputra River is one of the largest river in India originating at an altitude of $5300 \mathrm{~m}$ from Kanglung Kung glacier $\left(30^{\circ} 31^{\prime} \mathrm{N} ; 82^{\circ} 10^{\prime} \mathrm{E}\right), 63 \mathrm{~km}$ south of Mansarowar Lake in Tibet and flows $225 \mathrm{~km}$ in Arunachal Pradesh as Siang or Dihang before meeting the Lohit and Dibang rivers near Sadiya where from it is known as the Brahmaputra. In Bangladesh the river is known as the Padma / Yamuna.

The Brahmaputra River has a drainage area of 518,000 sq. km (Fig. 1) as derived from SRTM (Shuttle Radar Topographic Mission) DEM (digital elevation model) using River Tools 3.0 software. Of the total catchment area about 50.5 percent lies in China, 33.6 percent in India, 8.1 percent in Bangladesh and 7.8 percent in Bhutan. It's basin in India is shared by Arunachal Pradesh (41.88\%), Assam (36.33\%), Nagaland (5.57\%), Meghalaya (6.10\%), Sikkim (3.75\%) and West Bengal (6.47\%). revision accepted: 10 April 2011

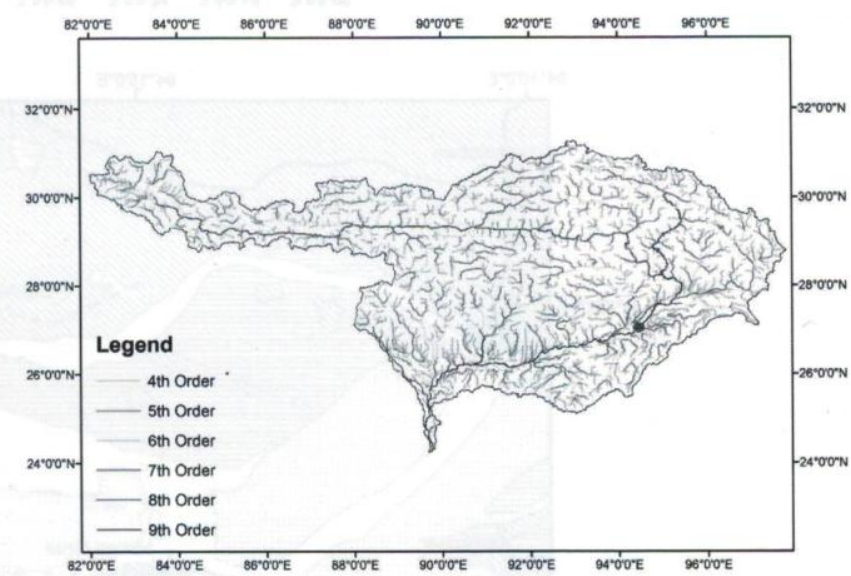

Fig. 1 : Drainage network of the Brahmaputra River. The solid circle represents the location of the study area.

\section{STUDY AREA}

Hatishal area is located along the bank of the Brahmaputra between Janjhimukh and Majuli in Jorhat District of Assam, India extending more than $12 \mathrm{~km}$ in length and lies between the geographical coordinates $26^{\circ} 51^{\prime} 45^{\prime \prime} \mathrm{N}: 94^{\circ} 14^{\prime} 25^{\prime \prime} \mathrm{E}$ and $26^{\circ} 53^{\prime} 46^{\prime \prime} \mathrm{N}$ : $94^{\circ} 20^{\prime} 58^{\prime \prime} \mathrm{E}$ (Figs. 2 and 4). 
Jorhat District of Assam, India represents mainly the plain of Brahmaputra Valley at an altitude of 80-120 m above MSL (Fig. 3). Altitudes above $120 \mathrm{~m}$ represent the foothill region of the Naga-Patkai hill range in the southern part of the district. The altitude of these hills ranges between 150 and $450 \mathrm{~m}$ above MSL. The relief map expressed a distinct fluvial fan of the Bhogdoi River passing through the district meridionally, the proximal part located along the Naga Hills and distal part extending upto the present study area along southern bank of the Brahmaputra, south of Majuli Island (Figs. 4 and 5). It is noteworthy that the Brahmaputra takes a northwesterly trend in front of the fan. Probably the fluvial fan is restricting the Brahmaputra erosion process in the western part of the district.
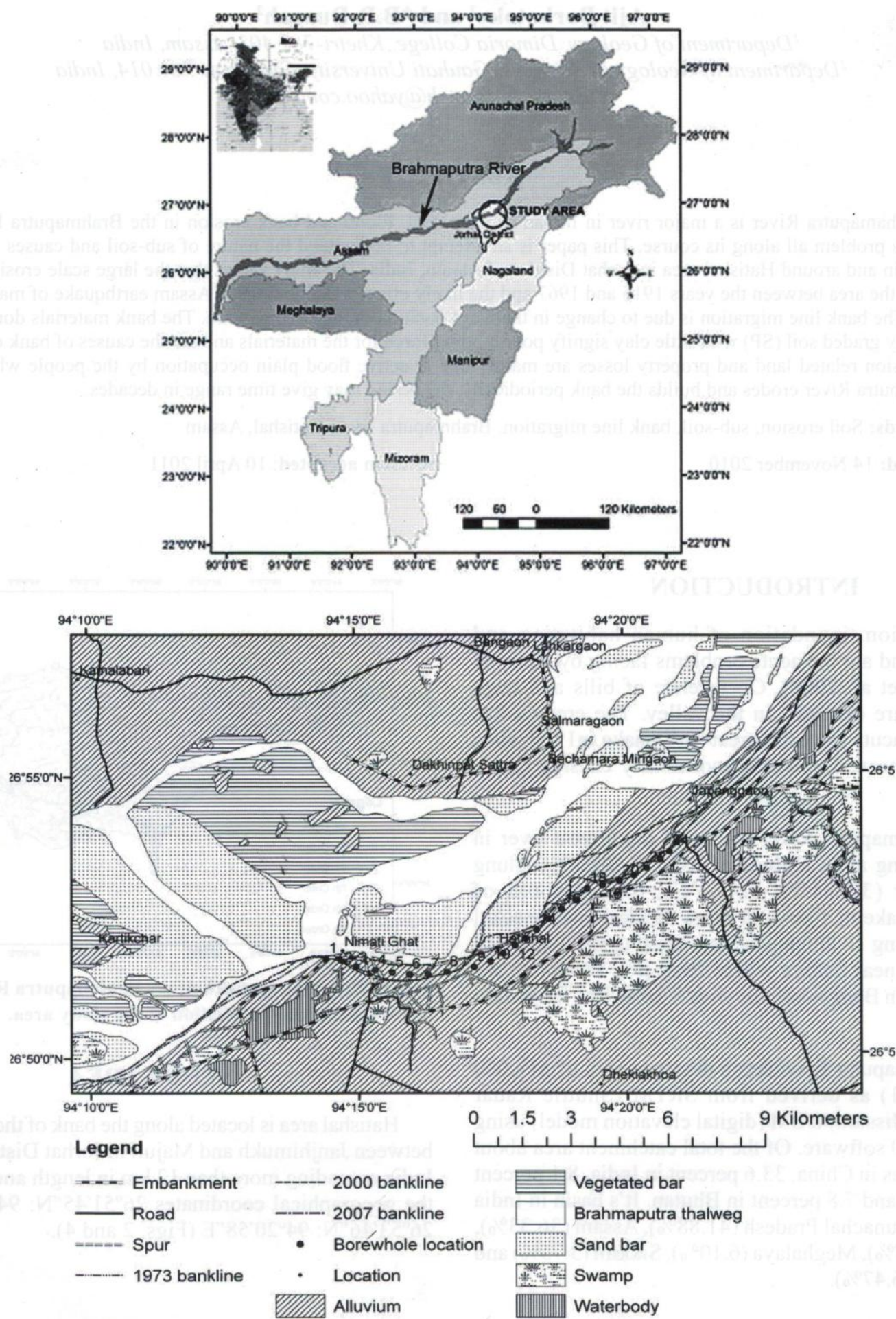

Fig. 2: Detail map of the study area 


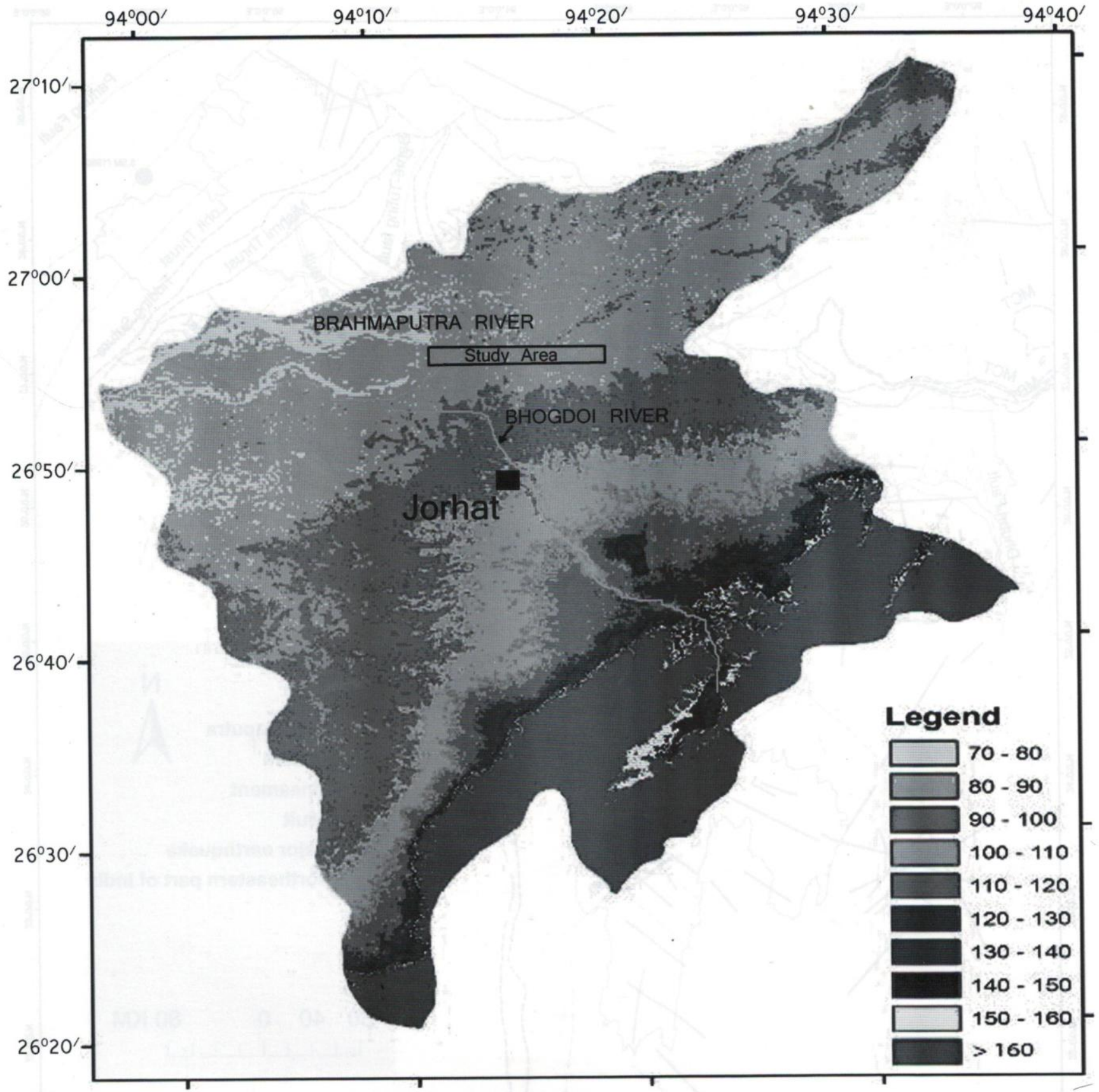

Fig. 3: Relief map of the Jorhat District prepared from SRTM data. The Bhogdoi River fan is clearly discernable in the map. The relief classes have the values in meter above MSL.

The average annual rainfall of the Brahmaputra basin is $215 \mathrm{~cm}$. In the study area around Hatishal, including Jorhat District, records an average rainfall of more than $200 \mathrm{~cm}$ annually (Ahmed 1986).

\section{SEISMICITY AND NEOTECTONICS ACTIVITIES}

The northeastern part of Indian subcontinent is one of the seismically most active regions of the world (Oldham 1899; Gutenberg 1956; Richter 1958; Evans 1964; GSI 1989; Duarah 2008). Among the most devastating earthquakes are the great earthquakes of 12 June, $1897(8.7 \mathrm{M})$ and 15 August, 1950 (8.5 M). The epicenter of the first earthquake was 


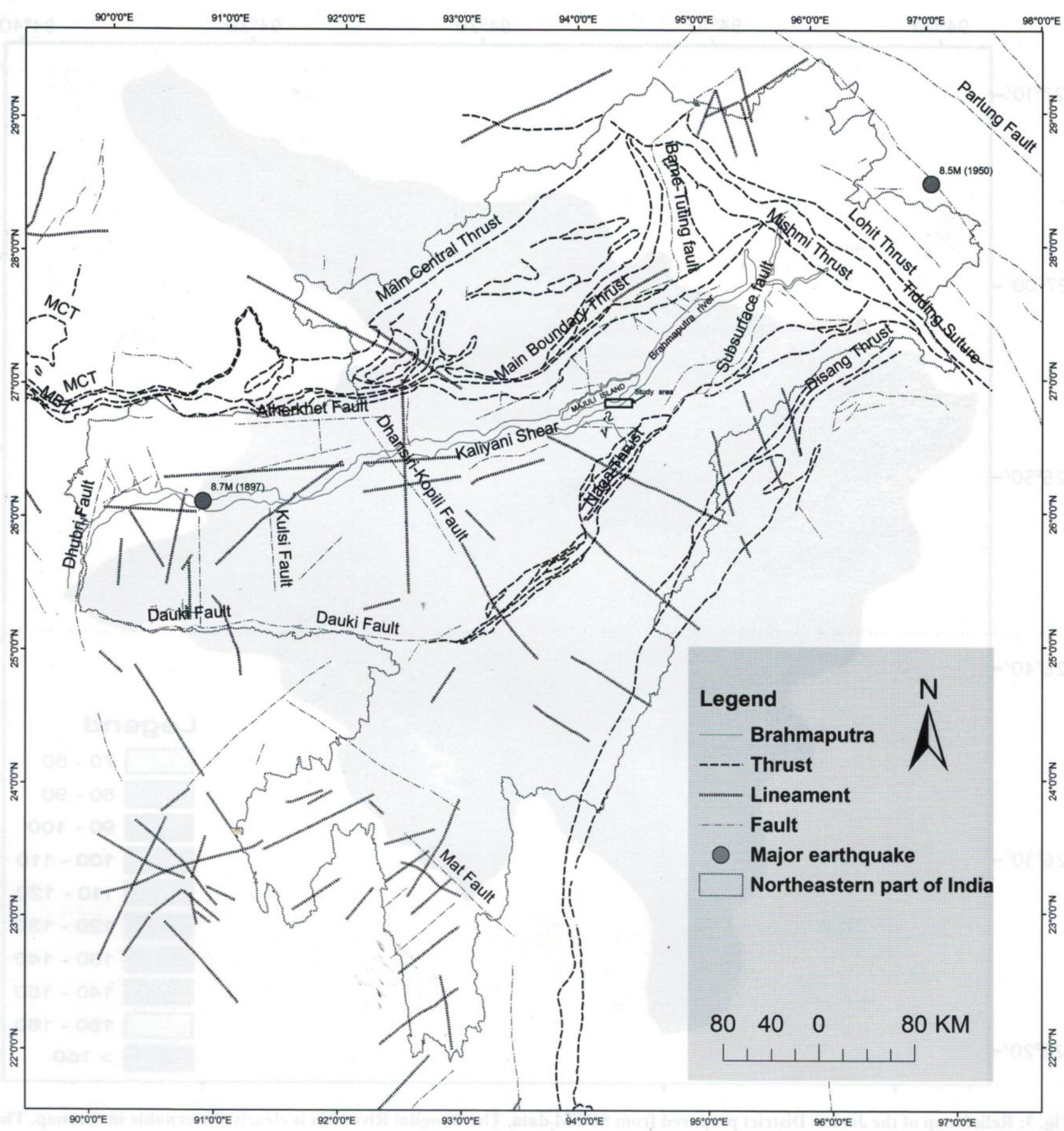

Fig. 4: Tectonic map of the northeastern part of India, compiled from GSI (2000) and Landsat-7 ETM+, IRS LISS-III satellite image interpretation. The dark rectangle indicates the study area. 1- Jorhat Fault, 2-Bhogdoi River

in the Shillong Plateau and the other in the eastern Mishmi region at Rima, near the tri-junction of India, China and Myanmar (Fig. 4). Its damaging intensity was such that the Brahmaputra River beds got uplifted (Goswami 1985) by several meters, accelerated sediment input to the river channel have taken place from the surrounding hills.

\section{BANK EROSION AND CHANNEL MIGRATION}

The seasonal flood and bank line migration are very common in some vulnerable reaches of the Brahmaputra (Kotoky et al. 2003; Sarma and Phukan 2004). After the Great Assam earthquake of 1950 (Poddar 1952), the area has been subjected to fury of flood during Monsoon causing 
It has been observed that area of section A, B, C and D suffered pronounced erosion during 1915 to 1967-68. During that period $\mathrm{E}, \mathrm{F}$ and $\mathrm{G}$ sections got fill up by the river. The total amount of lateral bank migration during the period 1915 to 2007 ranged from 73 to 2234 meters. It is evident from the Table 1 that there was large variation in amount of area eroded or fills up in different section during whole periods. It is observed from Table 1 that erosion was predominant in some of the areas while in some other areas deposition was dominant in the same time span. These data reveal that amount of bankline erosion and fill up by the alluvial soil of Brahmaputra River in different sections are not uniform.

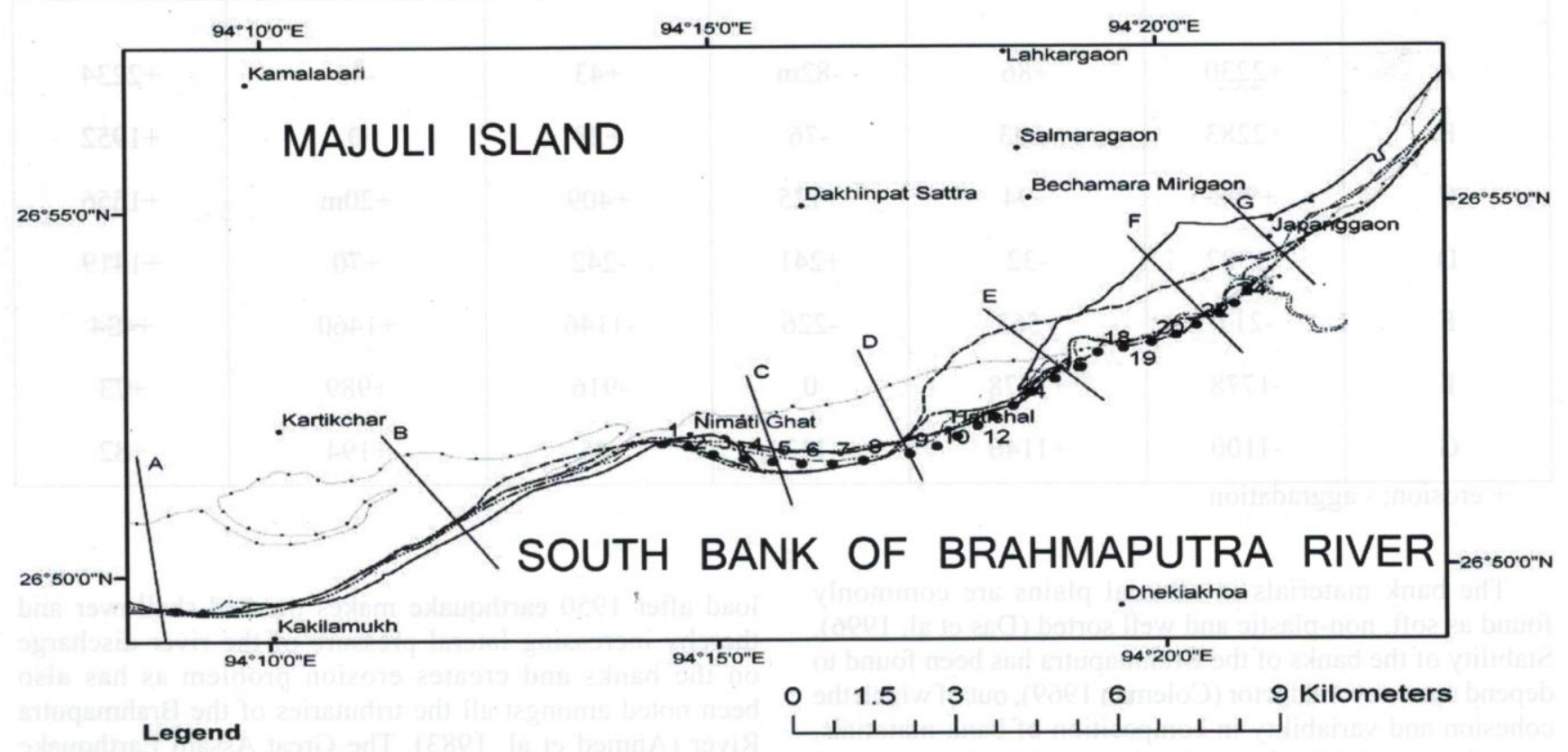

Legend

1915-16 -... 1990 Borehole location

Fig. 5: Bankline migration of the south bank of the Brahmaputra along Nimati-Hatishal area. 1, 2, 3,...., 25 are the boreholes where sediments have been collected to investigate their engineering properties.

acute erosion problem. Preceding this earthquake, the $7.7 \mathrm{M}$ earthquake of 29 June, 1947 (Latitude $28^{\circ} 30^{\prime} \mathrm{N}$ and longitude $94^{\circ} \mathrm{E}$; International Seismological Data Centre, ISC) had already left trails of destruction in the Eastern Himalaya, which brought down large scale morphological changes in the Brahmaputra River due to siltation and change in its hydrological regime (Poddar 1952). A $12 \mathrm{~km}$ long stretch of the Brahmaputra River bank has been suffering from severe erosion since 1950 in and around Hatishal. The bank erosion has been estimated from the Survey of India topographic maps of 1915-16 and 1967-68, satellite images acquired on 15-11-1973 (Landsat MSS), 09-11-1990 (Landsat TM), 2811-2000 (Landsat ETM+), 16-11-2007 (IRS-1C LISS-III). In the study we use the UTM WGS84 projection of Landsat ETM + image as standard and all other data set have been converted to this projection in ArcGIS platform. Then the banklines of the Brahmaputra River from the georeferenced data set of those periods (1915-2007) are superimposed. In order to have a detail idea about the bank erosion and channel aggradations during that periods the entire study stretch has been divided into seven sections (A,B,C,D,E,F,G), extending about $25 \mathrm{~km}$ in length. The amount of bank erosion and aggradation in different section/segments are given in Table 1 .
We also compared the thalwegs of the Brahmaputra in the segment for years 1915-16, 1967-68, 1973, 1990, 2000 and 2007 (Fig. 6). In 1915-16, a major channel of the Brahmaputra was flowing about $1.5 \mathrm{~km}$ north of Hatishal (east of section D in Fig. 4). In 1967-68, the Brahmaputra was eroding the Hatishal village, thus migrating $1.5 \mathrm{~km}$ towards south during a period of 52 years. One of the thalwegs of the Brahmaputra was very well established near Hatishal by $1967-68$. By 1973, the thalweg receded from Hatishal area but accelerated erosion took place in Nimatighat at the downstream. Thus aggradations of bank at Hatishal propagated the erosion problem in Nimatighat area by the year 1973. By the year 1990, there is severe erosion between Hatishal and Nimatighat. The main thalwegs which was located towards the north bank during 1973 now entirely shifted to the south bank passing through Hatishal. By the year 2000, the 1990's thalwegs gradually migrated towards Nimatighat and erosion near Hatishal has been halted. By the year 2007, the thalwegs further shifted towards west of Nimatighat and takes a northerly course, thus relieving the south bank erosion in the Nimatighat Hatishal area. 
Table 1: Lateral bankline progression and recession at Hatishal-Nimatighat section during the period 1915-2007 in metres.

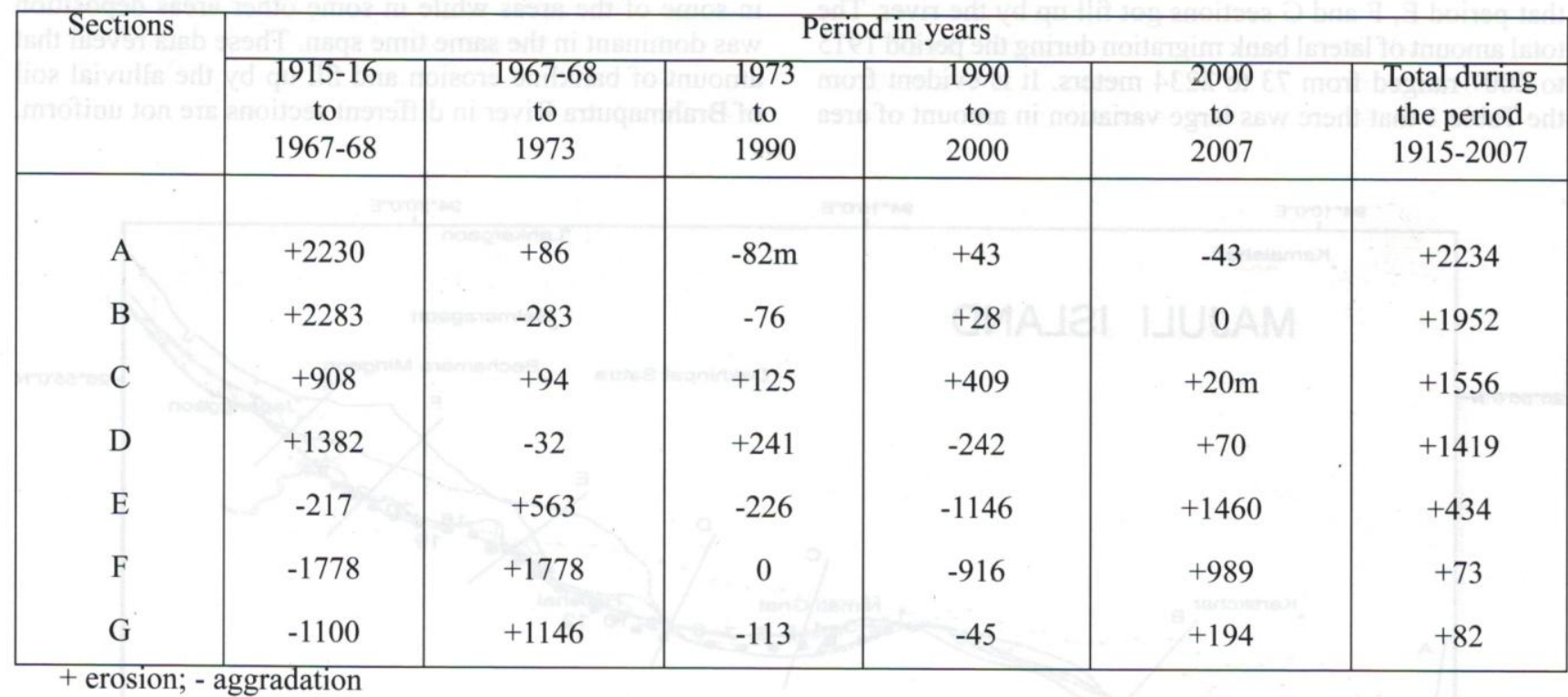

The bank materials in alluvial plains are commonly found as soft, non-plastic and well sorted (Das et al. 1996). Stability of the banks of the Brahmaputra has been found to depend upon several factor (Coleman 1969), out of which the cohesion and variability in composition of bank materials, rate of rise and fall of river level as well as discharge and the angle at which the thalweg approaches the bank (Sarma and Phukan 2006) are the major factors. Along the channel of the Brahmaputra, bank materials are homogeneous in composition, and result in bank slumping. The bank erosion is due to change in thalweg positions in the Brahmaputra, and the existing bank material which are mainly of poorly graded soil (SP) with little clay signifying poor binding force for the materials. The erosion related land and property losses are mainly due to temporarily relieved riverine tracts in the flood plains which are reoccupied by the Brahmaputra in subsequent periods by adjusting themselves to the changing position of the thalwegs.

Structural interpretation of the Jorhat area reveals presence of a fault zone (Fig. 4) running from Naga Thrust, south of Teok through Jorhat and Dergaon in the south bank of the Brahmaputra up to the south of Helam in Sonitpur District in the north bank across the Brahmaputra. The thickness of alluvium in the northern side of the fault zone is more than $1000 \mathrm{~m}$ while that of the southern block is about 500m (Ray 1981). The 15th August, 1950 Great Earthquake of Upper Assam seems to have slightly reactivated this fault, which caused so much damage to the town of Jorhat and the neighborhood.

The progression and recession data (Table 1) reflects the effects of the Great Assam Earthquake on the bankline migration pattern and channel configuration. Excessive silt load after 1950 earthquake makes the bed shallower and thereby increasing lateral pressure of the river discharge on the banks and creates erosion problem as has also been noted amongst all the tributaries of the Brahmaputra River (Ahmed et al. 1983). The Great Assam Earthquake of 1897 (M 8.7) with its epicenter in the Shillong Plateau have brought drastic changes in the physiography of the Brahmaputra valley mainly in the lower reach which resulted shallowing of the Brahmaputra River bed (Oldham 1899; Rajendran et al. 2004). The investigated data also indicate that the effect of the earthquake gradually reduces and the main channels have been trying to recapture its original channel configuration.

The excessive silt load resulted from the two great earthquakes of 1897 and 1950 that have occurred in Assam make the bed level rise rapidly, and to adjust the cross sectional area of the river required for water discharge the river spreads along the banks bringing large valley tracts under its jurisdiction. The response to this changing situation the river dynamically adjusted by eroding some part of the banks and depositing in some section of the rivers. The poorly graded non-cohesive (SP) soil with intermediate degree of permeability and top soil composed mostly of less permeable and high compressibility soft clay are easily eroded by the river current, and as such the soils are sensitive for erosion even at the slight increase in velocity of river water during monsoon. From the study of satellite images it has also been observed that the flow of the main channel of the Brahmaputra river when aligns towards Nimatighat Hatishal bank, the erosion process accelerates. 

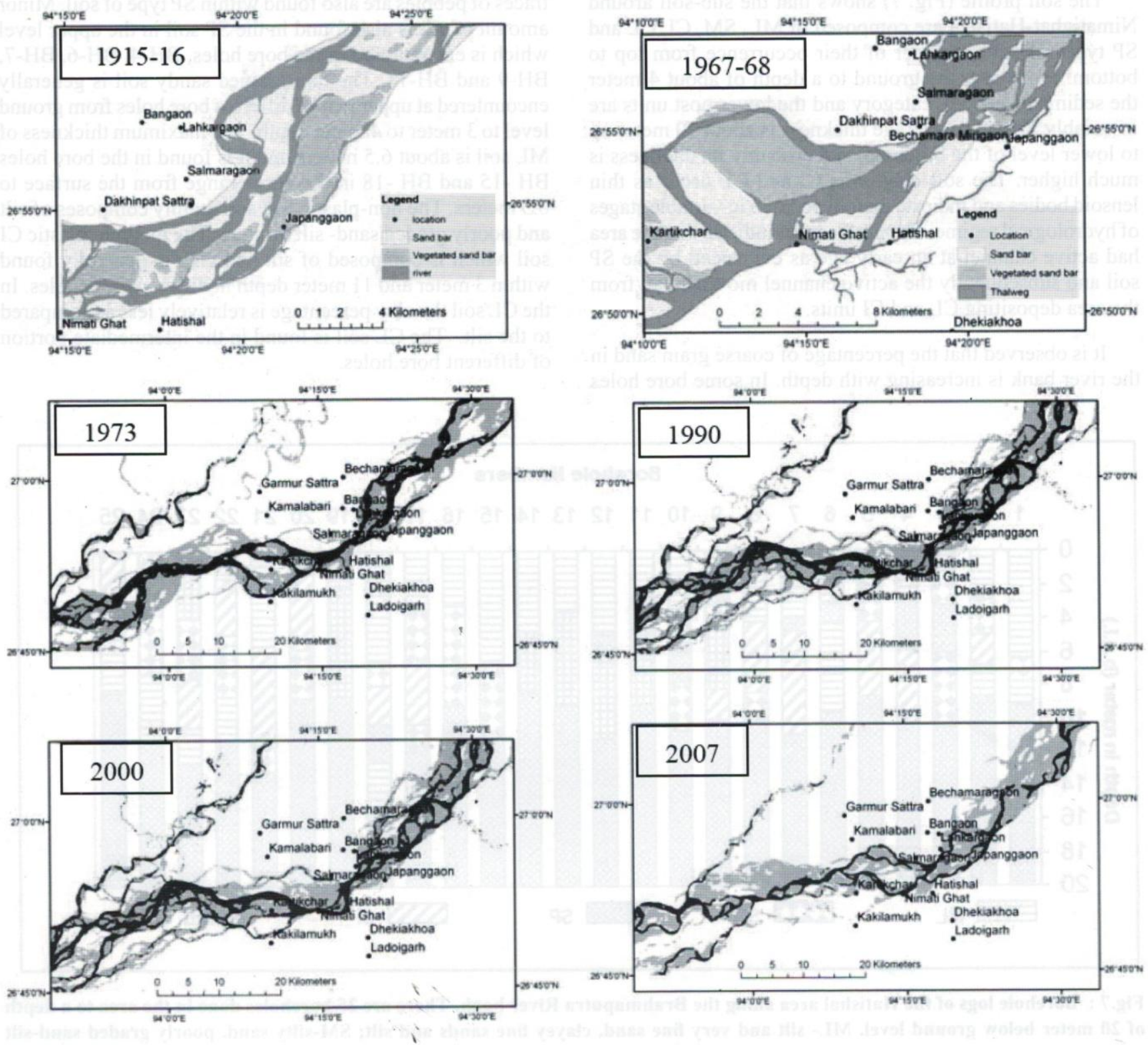

Fig. 6: Thalweg (dark continuous bands) position of the Brahmaputra in Nimati Ghat-Hatishal area during the years 1915-16, 1967-68, 1973, 1990, 2000 and 2007

\section{SOIL MECHANICS}

To find out the causative factors of soil erosion detail understanding of soil properties is essential (Oza 1969; Ranjan and Rao 2000). Soil classification is based on the IS: 1498-1970 (Indian Bureau of Standard soil classification) Considering practical utility, the study on soil mechanics has been under taken to address the erosional problem of Hatishal area. The standard penetration test in soil provides information on stiffness and variable properties of soils, especially for the cohesionless soils, from which it is difficult to obtain undisturbed sample. This test revealed the presence of SP, SM, ML, CL, and CI type of soil of which SP type soil was found to occur abundantly in the lower portion at the depth range of 10-20 meters. The minor units of CI and CL type soils present in the bank material possess less compactness. Since the river bank is more than 10 meter in height, the SP soil dominating zone of the river bank is most frequently comes under the attack of river current. This results undercutting and is the initiator of all forms of bank failure. 
The soil profile (Fig. 7) shows that the sub-soil around Nimatighat-Hatishal are composed of ML, SM, CI, CL and SP types of soils in order of their occurrence from top to bottom. From near the ground to a depth of about 4 meter the sediments are ML category and the lowermost units are invariably SP whose average thickness is about 10 meter up to lower level of the borehole, and probably its thickness is much higher. The soft clay units CI and CL occur as thin lensoid bodies and indicate their deposition in variable stages of hydrological regime. The profiles also indicate that the area had active channel at an early age as evidenced by the SP soil and subsequently the active channel moves away from the area depositing CL and CI units.

It is observed that the percentage of coarse grain sand in the river bank is increasing with depth. In some bore holes traces of pebbles are also found within SP type of soil. Minor amount of silt is also found in the SP soil in the upper level which is encountere in the bore holes, $\mathrm{BH}-4, \mathrm{BH}-6, \mathrm{BH}-7$, $\mathrm{BH}-9$ and $\mathrm{BH}-11$. The fine grained sandy soil is generally encountered at upper part of different bore holes from ground level to 3 meter to 4 meter depth. The maximum thickness of ML soil is about 6.5 meters and it is found in the bore holes $\mathrm{BH}-15$ and $\mathrm{BH}-18$ in the depth range from the surface to 6.5 meters. The non-plastic SM soil mainly composes of silt and poorly graded sand- silt mixture. The medium plastic $\mathrm{CI}$ soil which is composed of silt and clay is generally found within 3 meter and 11 meter depth in different bore holes. In the CL soil the clay percentage is relatively less as compared to the silt. The CL soil is found in the intermediate portion of different bore holes.

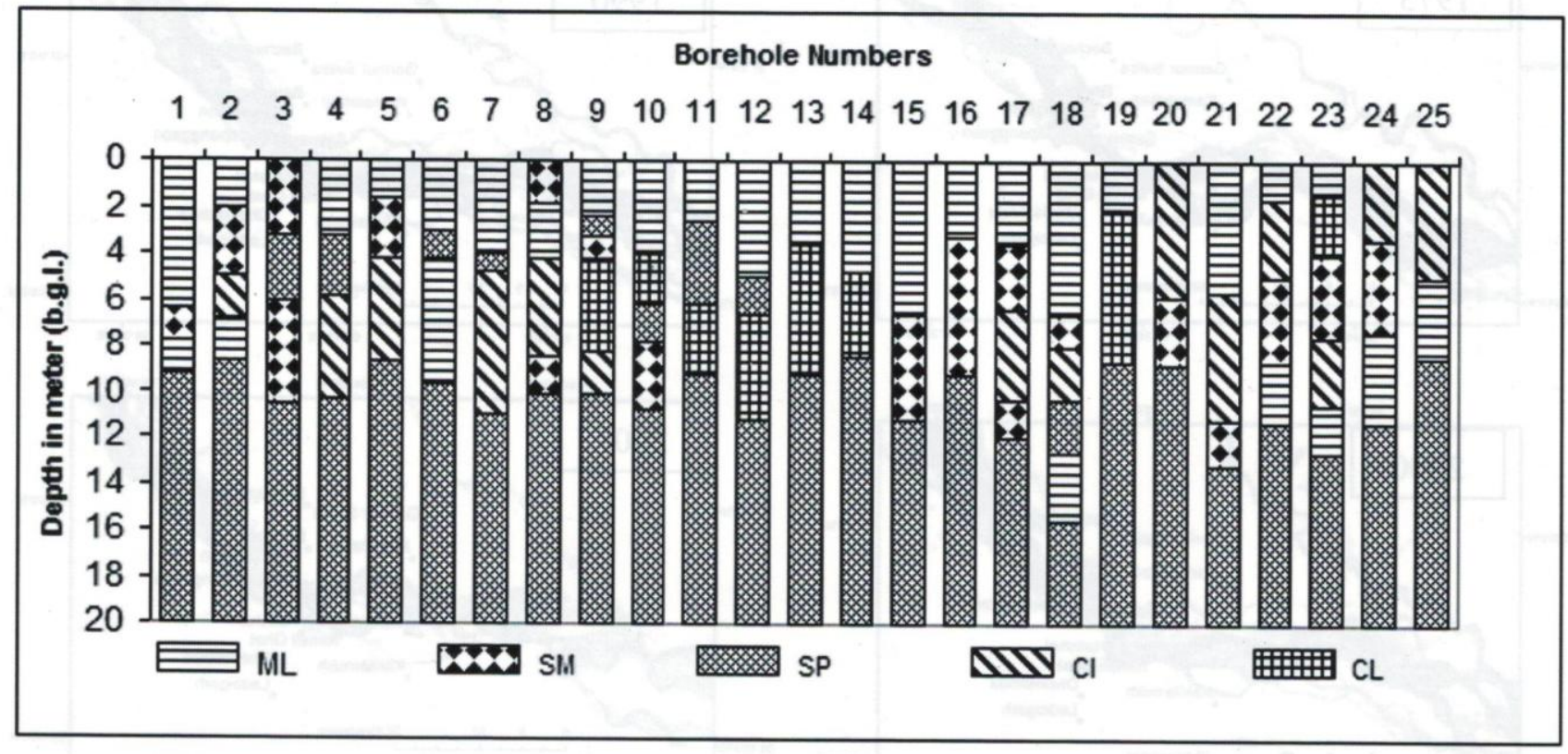

Fig.7 : Borehole logs of the Hatishal area along the Brahmaputra River bank. There are 25 boreholes done in the area to a depth of 20 meter below ground level. ML- silt and yery fine sand, clayey fine sands and silt; SM-silty sand, poorly graded sand-silt mixture; SP- poorly graded soil; CI-silty clay of medium plasticity CL-silty clay of low plasticity

Table 2: Summary of void ratio, porosity and co-efficient of permeability

\begin{tabular}{|c|c|c|c|c|c|c|c|c|c|}
\hline \multirow[t]{2}{*}{$\begin{array}{l}\text { Sub- } \\
\text { soil }\end{array}$} & \multicolumn{3}{|c|}{ Void ratio } & \multicolumn{3}{|c|}{$\begin{array}{c}\text { Porosity } \\
\%\end{array}$} & \multicolumn{3}{|c|}{$\begin{array}{l}\text { Co-efficient of permeability } \\
\mathrm{K} \\
\left(\times 10^{-4} \mathrm{~cm} / \mathrm{sec}\right)\end{array}$} \\
\hline & $\begin{array}{l}\text { Maxi- } \\
\text { mum }\end{array}$ & $\begin{array}{l}\text { Mini- } \\
\text { mum }\end{array}$ & $\begin{array}{l}\text { Aver- } \\
\text { age }\end{array}$ & $\begin{array}{l}\text { Maxi- } \\
\text { mum }\end{array}$ & $\begin{array}{l}\text { Mini- } \\
\text { mum }\end{array}$ & Ave-rage & $\begin{array}{l}\text { Maxi- } \\
\text { mum }\end{array}$ & $\begin{array}{l}\text { Mini- } \\
\text { mum }\end{array}$ & $\begin{array}{l}\text { Aver- } \\
\text { age }\end{array}$ \\
\hline ML & 1.75 & 0.37 & 7.49 & 63.72 & 27.01 & 43.61 & 21.00 & 0.049 & 1.24 \\
\hline SM & 1.08 & 0.40 & 0.65 & 52.37 & 28.84 & 38.07 & 18.60 & 0.044 & 1.82 \\
\hline CI & 1.66 & 0.44 & 0.90 & 62.37 & 30.69 & 46.68 & 6.60 & 0.013 & 0.54 \\
\hline CL & 1.66 & 0.44 & 0.95 & 62.00 & 30.54 & 46.28 & 9.50 & 0.014 & 1.40 \\
\hline SP & 1.13 & 0.40 & 1.70 & 53.27 & 29.82 & 39.07 & 68.50 & 0.066 & -- \\
\hline
\end{tabular}


The co-efficient of permeability (Table 2) test revealed that most of the SP soils have wide variation in permeability values. The top soil which is composed of vegetal matters has lowered co-efficient of permeability. The permeability values for the cohesive bands of CI and CL are less indicating impervious nature of the soil.

The wet and dry density test revealed that the soil of the investigating area is generally composed of dense and loose mixed grain sandy soil. The wet density and dry density of the soil in the study area ranges from $1.45 \mathrm{gm} / \mathrm{cc}$ to $2.30 \mathrm{gm} /$ $\mathrm{cc}$ and $0.85 \mathrm{gm} / \mathrm{cc}$ to $1.98 \mathrm{gm} / \mathrm{cc}$ respectively.

Table.3: Data of Liquid Limit, Plastic Limit and Plastic Index

\begin{tabular}{|c|c|c|c|c|c|}
\hline & $\begin{array}{l}\text { Depth } \\
\text { (in meter) }\end{array}$ & Soil type taken & $\begin{array}{l}\text { Liquid Limit } \\
\quad \text { (in \%) }\end{array}$ & $\begin{array}{l}\text { Plastic Limit } \\
\quad \text { (in \%) }\end{array}$ & Plastic Index \\
\hline 1 & $9.90-10.5$ & SP & 30.6 & 18.97 & 11.63 \\
\hline 2 & $5.40-6.00$ & $\mathrm{CI}$ & 48.7 & 31.2 & 17.5 \\
\hline 3 & $6.90-7.50$ & SM & 30.2 & 19.55 & 10.65 \\
\hline 4 & $9.90-10.5$ & $\mathrm{CI}$ & 39.4 & 22.1 & 17.3 \\
\hline 5 & $6.90-7.50$ & $\mathrm{CI}$ & 54.8 & 35.64 & 19.16 \\
\hline 6 & $8.40-9.00$ & ML & 30.5 & 18.5 & 12 \\
\hline 7 & $8.40-9.00$ & $\mathrm{CI}$ & 43.3 & 23.85 & 19.45 \\
\hline 8 & $8.40-9.00$ & SM & 29.2 & 18.85 & 10.35 \\
\hline 9 & $3.90-4.50$ & SM & 34.38 & 21.83 & 12.55 \\
\hline 10 & $6.90-7.50$ & SP & 32.5 & 20.38 & 12.12 \\
\hline 11 & $5.40-6.00$ & SP & 32.61 & 18.61 & 14 \\
\hline 12 & $9.90-10.5$ & $\mathrm{CL}$ & 46.5 & 26.92 & 19.58 \\
\hline 13 & $6.90-7.50$ & CL & 30.85 & 18.08 & 12.77 \\
\hline 14 & $9.90-10.5$ & SP & 30.21 & 19.98 & 10.25 \\
\hline 15 & $8.40-9.00$ & SM & 30.47 & 18.47 & 12 \\
\hline 16 & $8.40-9.00$ & SM & 37.34 & 22.84 & 14.5 \\
\hline 17 & $8.40-9.00$ & $\mathrm{CI}$ & 49.65 & 26.44 & 23.21 \\
\hline 18 & $2.40-3.00$ & ML & 33.63 & 17.11 & 16.52 \\
\hline 19 & $6.90-7.50$ & $\mathrm{CL}$ & 30.09 & 18.08 & 11.21 \\
\hline 20 & $3.90-4.50$ & $\mathrm{CI}$ & 45.9 & 27.43 & 18.47 \\
\hline 21 & $3.90-4.50$ & ML & 33.86 & 22.48 & 11.38 \\
\hline 22 & $9.90-10.5$ & ML & 34.33 & 20.65 & 13.68 \\
\hline 23 & $2.40-3.00$ & $\mathrm{CL}$ & 29.2 & 9.8 & 19.4 \\
\hline 24 & $2.40-3.00$ & $\mathrm{CI}$ & 45.9 & 26 & 19.9 \\
\hline 25 & $9.90-10.5$ & SP & 24.04 & 12.38 & 11.66 \\
\hline
\end{tabular}

The SP soil has low to high moisture content in the range of $16.15 \%$ to $46.71 \%$ with corresponding dry density of $1.21 \mathrm{gm} / \mathrm{cc}$ to $1.88 \mathrm{gm} / \mathrm{cc}$. This wide variation in moisture content is one of the responsible factors the considerable erosion in the area. The presence of large volume of water content makes the soil to behave more or less like fluid, thereby, facilitating erosion through liquefaction. The maximum and minimum percentages of soil moisture in CI soil are $21.57 \%$ and $63.29 \%$, and CL soil are $22.12 \%$ and
$42.01 \%$ respectively. The dry density of cohesive soil of the area ranges in between 0.86 to $1.72 \mathrm{gm} / \mathrm{cc}$. The ML soil also indicates medium to high water content with dry density ranges in between $1.01 \mathrm{gm} / \mathrm{cc}$ to $1.78 \mathrm{gm} / \mathrm{cc}$. The SM soil also has moisture content with a range from $16.00 \%$ to $48.57 \%$.

The specific gravity (sp.gr.) of the soil samples of the study area ranges between 2.38 and 2.78 . The poorly graded sandy SP soil is having sp. gr. value between 2.59 to 2.77 . The higher specific gravity value units are compact and heavier, and can withstand the scouring and lifting action of the water current. Unfortunately, these units are nearly free from clay minerals and as such possess very low plasticity. 
Table 4: Average liquid limit, plastic limit, plastic index, cohesion (C) and angle of internal friction $\varnothing$

\begin{tabular}{|cccccc|}
\hline Sub-soil & $\begin{array}{c}\text { Average Liquid } \\
\text { Limit } \%\end{array}$ & $\begin{array}{c}\text { Average Plastic } \\
\text { Limit } \%\end{array}$ & $\begin{array}{c}\text { Average Plastic } \\
\text { Index }\end{array}$ & $\begin{array}{c}\text { Average } \\
\text { Cohesion } \\
\text { (c) kg/cm }{ }^{2}\end{array}$ & $\begin{array}{c}\text { Average Angle } \\
\text { of internal friction } \\
\varnothing \text { in degree }\end{array}$ \\
\hline ML & 33.08 & 19.68 & 13.39 & 0.05 & $23^{\circ}$ \\
CI & 46.01 & 27.52 & 17.85 & 0.06 & $22^{\circ}$ \\
CL & 43.16 & 18.22 & 15.74 & 0.05 & $23^{\circ}$ \\
SM & 32.32 & 20.3 & 12.01 & 0.03 & $20^{\circ}$ \\
SP & 30.1 & 18.06 & 11.62 & 0 & $30^{\circ}$ \\
\hline
\end{tabular}

The Atterberg limit test (IS: 2720 Part V, 1970) shows that the liquid limit and plastic limit of SP soil is very less (Table-3). On the other hand cohesive CI and CL soils possess a low to medium plasticity. For the CI soil the average liquid limit and plastic limit are $46.01 \%$ and $27.74 \%$ respectively. The CL soil also indicates low plasticity, (average $34.16 \%$ ). The SM soil is also showing average plastic limit of $20.30 \%$. The ML type soil also shows low plasticity (average $19.68 \%$.).

The standard penetration test indicates that the $\mathrm{N}$-value of the soils around Hatishal ranges between 5 blows $/ 30 \mathrm{~cm}$ and 290 blows $/ 30 \mathrm{~cm}$ in the bore hole 6 and bore hole 8 respectively (Table-4). In the predominant SP soil, the $\mathrm{N}$-value has wide variation. It is generally noticed that in SP soil, the N-value increases with depth due to increase of compactness at depth. It is due to the variation in compactness of the soil with increased depth. The N-value of ML soil is found within 2 blows $/ 30 \mathrm{~cm}$ to 37 blows $/ 30 \mathrm{~cm}$. The $\mathrm{SM}$ soils have $\mathrm{N}$-value ranges from 4 blows $/ 30 \mathrm{~cm}$ to $32 \mathrm{blows} / 30 \mathrm{~cm}$ in the borehole 21 and borehole 8 respectively. The $\mathrm{N}$-value of CI and CL cohesive soils indicate very soft to medium relative consistency.

The angle of internal friction (Ø) of non- cohesive SP soil is $25^{\circ}$ to $33^{\circ}$ and $\mathrm{C}$ values is zero. It is observed that the $(\varnothing)$ value is increasing with depth as diameter of soil particles become larger and compactness of soil become denser. The shear strength of the cohesive soil is very much affected by the moisture content The $(\varnothing)$ value for cohesive soils CI and CL ranges in between $19^{\circ}$ to $29^{\circ}$ with cohesive (C) value 0.03 $\mathrm{kg} / \mathrm{cm}^{2}$ to $0.13 \mathrm{~kg} / \mathrm{cm}^{2}$. The fine grained ML soil also has C value between $0.05 \mathrm{~kg} / \mathrm{cm}^{2}$ and $0.16 \mathrm{~kg} / \mathrm{cm}^{2}$ and $\varnothing$ varies between $17^{\circ}$ and $28^{\circ}$. The SM soil has less cohesion with $\varnothing$ value ranges from $12^{\circ}$ to $21^{\circ}$. In the study area it is observed that due to the decrease of moisture content with depth through reduced porosity by load of the sediment column, the cohesive factor $\mathrm{C}$ increases as moisture content largely affects the shearing strength of the soil.

\section{HYDROLOGY AND HYDROMETEOROLOGY}

The Brahmaputra is characterized by high seasonal variability in water discharge and sediment load. It is observed that the concentration of sediment load is related to water discharge i.e. increasing water discharge being accompanied by an increase in sediment concentration. During monsoon (June-September) about $60.71 \%$ of yearly discharge is observed. Monthly average sediment discharge of the Brahmaputra river in the study area is $18.50 \%$ as recorded at Bechamara in July. Bank erosion appears to be related to shear failure and undercutting of the banks during high discharge and pore water pressure action during recession of flood water.

\section{FLOOD, EROSION AND DAMAGE REDUCTION APPROCHES AT HATISHAL}

Erosion at Hatishal was not well pronounced since 1978 till 1988. During the years from 1989 to 1992 the main channel of the Brahmaputra attacked the bank in and around Hatishal at high obliquity with an angle of about $60^{\circ}$ to $70^{\circ}$. Due to this attack extensive bank erosion took place (Fig. 5). In this process, the almost entire old Nimatighat and the steel Railway Bridge, which was constructed on Kokila River, a tributary of the Brahmaputra, for the old railway extension line located in the close vicinity of the bank was eroded. During the flood vast areas of homestead and cultivated land were eroded. Road, railways and bridges, important public properties and institutions, domestic cattle, livestock and valuable human live were lost.

There are main three types of failure observed around the study area. The shear failure (Fig. 6), undercutting and pore water pressure / seepage. The other major cause of shear failure is over steeping of the bank materials as thalweg of the channel hug banks. In localities where bank materials are slightly cohesive, shear failure of the bank results in a related step-like structure leading from the lop of the bank to the water edge. Most of the shear planes diminish in the slope as they penetrate into sub-surfaces and as a result the blocks are tilted land-ward by rotation. The second types of failure is that during flood the river banks get saturated and in the time of falling floods the seepage flow starts through the bank due to excessive pore water pressure. The seepage flow increases at the lower stages due to higher water table in the flood plains and lower water levels in the river channel. As in the study area the banks are composed mainly of sand with little amount of clay having low cohesion, the bank gives way and collapses in the river and the collapsed sediments 
get washed away. This type of failure is a sub aqueous type's failure.

Erosion due to the Brahmaputra around Hatishal of Jorhat district becomes quite vulnerable since 1978 (Figs. 8 and 9). From last few years, the pattern of the river flow has been changing extensively and taking south-ward swing toward the Hatishal-Nimatighat areas hugging the southern bank at an angle of about $60^{\circ}$ to $70^{\circ}$ causing huge bank erosion. In spite of several short terms protection measures like bamboo and concrete porcupines bank revetments and normal apron were also tried from 1989 to 1992 unsuccessfully in the reach. After the alarming flood situation at Hatishal in the year 1993 a hydraulic model study was carried out by River Research Station of Government of Assam. The model study has recommended constructing 4 numbers of land spurs 2 numbers of bull heads) with 3 numbers of bed bars in 1994 . But due to changed river configuration the hydraulic model study has to be repeated in 1995. The later model study suggests constructing 3 numbers of land spurs and 2 numbers of bull heads as long terms bank protection measures. Based on the model study, the anti-erosion project, initially designed to protect Hatishal-Nimati area in north Jorhat on the south bank of the Brahmaputra River involved the construction of three spurs and two bullheads along with raising and strengthening of $3.14 \mathrm{~km}$ stretch of the strategic Bor Ali dyke running from Jhanjimukh to Nimati, when the NimatiHatishal project was started in February 1996 it cost was pegged at Rs.317.7 million. The five protective structures, covering a reach of $12 \mathrm{~km}$ were supposed to protect a total area of 10,800 hectors. Though these protection measures partially successful in case of embankments, occasionally they fails.

Erosion is a major factor of river instability due to very large amount of silt load coming from the river banks and causing more instability downstream. Total control of flood and erosion is not practicable from economic considerations and hence, flood management is essential. Flood management rationally refers provision of reasonably degree of protection against floods by structural or non-structural measures to minimize the loss of property and life caused by floods.

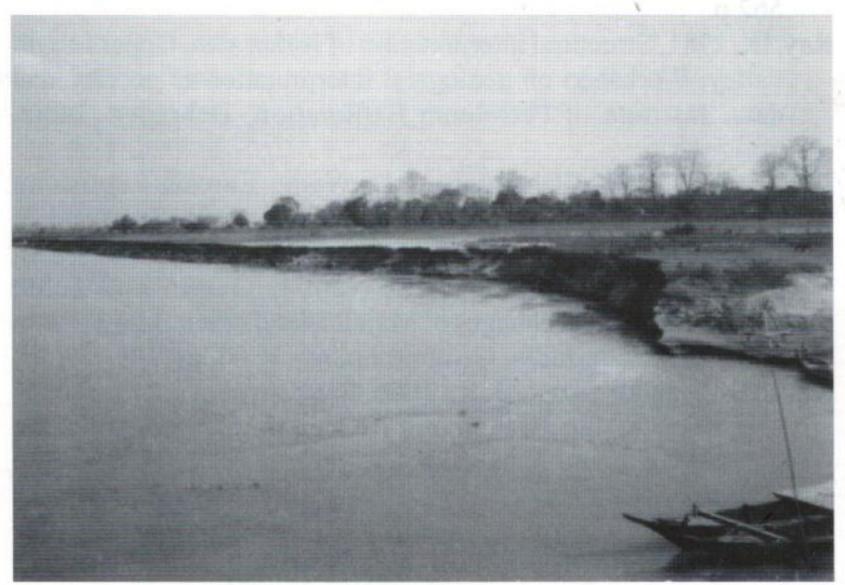

Fig. 8: River bank erosion of the Brahmaputra at Hatishal, Jorhat district, Assam

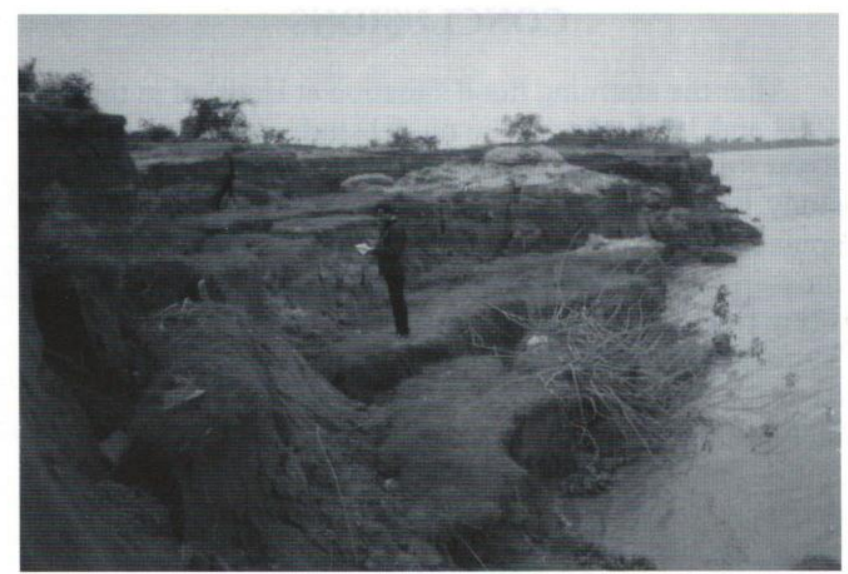

Fig. 9: Shear failure in the Brahmaputra River bank at Hatishal

The marginal dyke running from Jhanjimukh to Nimati is subjected to river water pressure and consequent severe erosion. In order to maintain the embankments in position, large-scale anti-erosion works like land spurs, bullheads and revetments are carried out, every year before the flood season by the Assam Government. Although these projects have put floods under efficient control the safety of flood plain areas and downstream condition is not guaranteed when the floods exceed the dyke standards. According to the realistic conditions we have to select the mode of flood risk management, i.e. to combine structural as well as nonstructural measures as an integrated whole with a view to local flood conditions on the basis of careful study on flood risk characteristics and trends of the Brahmaputra and its tributaries Non-structural measures like flood forecasting and warning system, flood insurance, flood plain zonation, change of cropping pattern, improving information system for post-flood recovery etc. should be utilized to impulse structural measures for more suitable and long-term benefits, reinforcing with policies of risk sharing and risk compensation, which may form a new water management strategy of living with rivers and floods.

It has been observed the local people construct public and private sheds and houses on and near the embankments in the area which are serious threats to the embankment stability, since the people are reducing the height of the embankments near the road junction to their houses, remove a major part of the embankment to maintain proper slope of the entrances of their houses located close to the embankments, the embankments designed properties is lost. The embankments become weak, its height reduced from its designed height bringing risk of over topping and breaching of embankments. Field enquire indicates that most of the local people, dominated by cultivators, poorly understand the threat they are creating. Solving the flood damage problems of the Brahmaputra basin, as presently protecting and enhancing the floodplain environment, needs full use of all the structural and non-structural methods available. 


\section{CONCLUSIONS}

After the alarming flood situation at Hatishal in the year 1993 and 1995 a hydraulic model study was carried out by River Research Station of Government of Assam. The model study has recommended constructing 3 numbers of land spurs 2 numbers of bull heads as long terms bank protection measures. The five protective structures, covering a reach of $12 \mathrm{~km}$ were supposed to protect a total area of 10,800 hectors. Though these protection measures partially successful in case of embankments, occasionally they fails with the spurs and bullheads Bank erosion appears to be related to shear failure and undercutting of the banks during high discharge and pore water pressure action during recession of flood water. Stability of the banks of Brahmaputra has been found to depend upon several factors out of which the cohesion and variability in composition of bank materials, rate of rise and fall of river level as well as discharge and the angle at which the thalweg approaches the bank are the major factors. Along the channel of the Brahmaputra, bank materials are homogeneous in composition, and result in bank slumping. The bank erosion is due to change in thalweg positions in the Brahmaputra, and the existing bank material which are mainly of poorly graded sandy soil (SP) with little clay signifying poor binding force for the materials. The erosion related land and property losses are mainly due to temporarily relieved riverine tracts in the flood plains which are reoccupied by the Brahmaputra in subsequent periods by adjusting themselves to the changing position of the thalwegs.

The field and laboratory investigation reveled that the sub-soil in and around Hatishal is composed of cohesive and non-cohesive soil. According to the realistic conditions we have to select the mode of flood risk management, i.e. to combine structural as well as non-structural measures as an integrated whole with a view to local flood conditions on the basis of careful study on flood risk characteristics and trends of the Brahmaputra and its tributaries.

\section{ACKNOWLEDGEMENTS}

The authors are thankful to Achyuta Koirala for his critical reviews and suggestions to improve this manuscript.

\section{REFERENCES}

Ahmed, H., 1986, On the erosional aspects of the Brahmaputra river around Maijan and Mathola, Dibrugarh Distict, Assam - A Geological Study. Unpublished Ph.D. Thesis, Gauhati University,

Ahmed, H., Masood, M. D., and Hazarika, I. M., 1983, On the erosional aspects of the Brahmaputra river at Maijan and Mathola, Dibrugarh District, Assam. Quaterly Jour. Geology and Mining. Meteorogical Society of India, v.55(1); p.31-35.
Coleman, J. M., 1969, Brahmaputra River channel process and sedimentation. Sediment. Geol., v.3, pp.129-239.

Das, P. K., Duarah, B. P., and Goswami, D. C., 1996, Channel migration study of the Pagladiya River, Assam using remote sensing and field survey data, Jour. Geoscience; v. 1, pp.38-45.

Duarah, B. P., 2008, Tectonic evolution, sedimentation and geodynamics of North-east India. In : North-East India, Geoenvironmental Issues, S. Deka [Ed.], 317 p., EBH Publishers (India), Guwahati, pp.1-30.

Duarah, B.P., Borkotoky, A., and Phukan, S., 2008, Bank migration in the Brahmaputra River in Nimati-Hatishal area in Assam, India. Jour. Soc. Environmental Protection, Education \& Research (SEPER), v. 3 (1).

Evans, P., 1964, The tectonic framework of Assam, Jour. Geol. Soc. India, v. 5 , pp. $80-96$.

Goswami, D. C., 1985, Brahmaputra River, Assam, India: Physiography -basin denudation and channel aggradation, Water Resources, v. 21, pp. 959-979.

GSI, 1989, Geology and tectonics of the Himalaya. Geological Surv. India, Spec. Pub., No.26, 192 p.

GSI, 2000, Seismo-tectonic Atlas of India and its environs, Geological Surv. India.

Gutenberg, B., 1956, Great earthquakes between the periods 1896 -1903 , Eos Trans. AGU, v. 37.

IS: 1498-1970, 1970, Classification and Identification of soils for general engineering purposes; Indian Bureau of Standard (ISI)

IS: 2720 Part V, 1970, Indian standard method of test for soil, Part $\mathrm{V}$, Determination of liquid and plastic limits.

Kotoky, P., Bezbaruah, D., Baruah, J., and Sarma, J. N., 2003, Erosion activity on Majuli - the largest river island of the world. Curr. Sci., v. 84, pp. 929-932.

Oldham, R.D., 1899, Report of the great earthquake of 12 th June 1897. Mem. Geol. Surv. India, v. 29, 379 p., Reprinted by Geol. Surv. of India, Calcutta, 1981.

Oza, H. P., 1969, Soil Mechaics and Foundation Engineering, Charotar Book Stall; $761 \mathrm{p}$.

Poddar, M. C.,1952, Preliminary report of the Assam earthquake, 15th August, 1950. Bull., Geological Surv. India, 40 p.

Rajendran, C. P., Rajendran, K., Duarah, B. P., Baruah, S., and Earnest, A., 2004, Interpreting the style of faulting and paleoseismicity associated with the 1897 Shillong northeast India, earthquake: Implications for regional tectonism. Tectonics, v. 23, TC4009, doi:10.1029/2003TC001605.

Ranjan, G. and Rao, A. S. R., 2000, Basic and Applied Soil Mechanics, New Age International Publishers, New Delhi, $562 \mathrm{p}$.

Ray, D., 1981, Structural interpretation of Jorhat area, Upper Assam valley; Workshop on geological interpretation of geophysical data. Institute of Petroleum Exploration, Dehradun, India, pp.15-18.

Richter, C., 1958, Elementary Seismology; Euresia Publishing House (Pvt.) Ltd. (Reprinted in India in 1969, S. Chand \& Company Ltd.), 768 p.

Sarma, J. N. and Phukan, M.K., 2004, Origin and some geomorphological changes of Majuli Island of the Brahmaputra River in Assam, India. Geomorphology, v. 60, pp.1-9.

Sarma, J. N. and Phukan, M. K., 2006, Bank Erosion and Backlines Migration of the Brahmaputra River in Assam during the Twentieth Century. Jour. Geol. Soc. India, v. 68, pp. 1023-1036. 